\title{
The Sense of Insecurity and the Language of Pinter's Absurd Play the Birthday Party
}

\author{
Marinela Saraci/Terpollari \\ PhD. Candidate, Lecturer of American\& English literature \\ "Aleksander Moisiu" University \\ marinelatrp@yahoo.com
}

\section{Doi:10.5901/mjss.2013.v4n11p384}

\begin{abstract}
This article introduces Pinter as an early practitioner of the Theater of the Absurd who clearly omits melodramatic and supernatural elements without any loss of mystery, interest or horror. The sense of horror and terror is still preserved by several other devices such as pauses and silences, which turned out to be his hallmarks. The absurdity used by Pinter can sometimes be funny and we can laugh at it, but his idea is to reflect how people felt in their own realities. He uses this comical way to laugh at everything, even at tragic situations. Another important feature of this play is the way how words are used as weapons to avoid being hurt and not to reveal the past. They evade direct communication so that they can evade the past and protect their territory. We will explain how territory is inevitably related to personal autonomy and security and how the characters achieve this through their language. The funny and comic side of the play is revealed and interpreted differently at the end of the play. It will change our view point of looking at things.
\end{abstract}

Keywords: Pinter, Theater of Absurd, Funny, Drama.

\section{Introduction}

Esslin, a critic, placed Pinter among other absurdist writers such as Adamov, Ionesco, Genet, Albee and Beckett... He used the phrase "Theatre of the Absurd", to describe the plays of the 1950sand 1960s. It has been derived from an essay by the French philosopher, Albert Camus, "Myth of Sisyphus" written in 1942, who defined the human situation as basically meaningless and absurd. "In the Theater of the Absurd," writes Esslin (1964 ), "the human condition is presented to us as a concrete poetic image that has become flesh on the stage and that is at the same time widely comic and deeply tragic" (241). This drama, which is Pinter's first full-length play, combines some of the characters and situations of The Room and The Dumb Waiter, while for the first time, omitting melodramatic, supernatural elements without any loss of mystery or horror. (Ibid. pp. 202).

What they have in common is exactly this sense of anguish, terror and menace that is felt throughout the whole play. The sense of absurdity of human life and the sense of territorial intrusion appear to be present even in this play. As in The Room, Stanley is not happy for the arrival of new guests, because he feels that his territory is being threatened. They are once again under the menace of being invaded and the sense of insecurity is felt throughout the play.

The human consciousness seemed to be facing an apparently absurd world, because it finds itself at the crossroads of "Being" and "Nothing". The two world wars affected the human soul and destroyed everything left. There seemed to be no meaning in that post war life. Everything was surrounded by a disbelief in God and humanity. No one could escape reality. Authors tried to reflect these consequences on human soul in theatre, poetry, novels etc. The same did Harold Pinter. He tried to reflect this sense of anguish that the humans were experiencing in this absurd post war existence. So from this point of view existentialism seemed inseparable from absurd and they cohabitated perfectly well.

The essence of the European Absurd theatre finds a new dimension in the plays of Pinter. He has shown the drawbacks and tension in the social life of today. His dramatic style and techniques are fundamental and served a lot to younger generations. His plays are not easy to grasp and understand. This is a main feature of all absurdist plays and works. He has denied the presence of any allegorical meaning in his plays. Brevity is the hallmark of Pinter's dialogue which naturally gives rise to many shades of meaning. The reader of Pinter's plays cannot always arrive at the exact meaning of the cryptic sentences, and one can draw many different ideas from them.

He may be considered the most challenging contemporary British dramatist who revolutionized our understanding of the theatre (Pandey.A;2013:19). Etheridge (1963) believes that Pinter has artistically employed "tactics derived from Kafka, Hemingway, and lonesco" (427).He seemed to have read all of the secondary sources-Beckett, Ionesco, and 
Genet. (Wellwarth, 1964: 197-198). Consequently, almost all of the writers who had influenced Pinter's dramaturgy were either founders or forerunners of the avant-garde Theatre of the Absurd.

Though very enlightening and helpful to the readers, the Theater of the Absurd has also been the cause of controversial views among readers and critics. Some have tried to prove that Pinter is a mere absurdist dramatist. Joseph Hynes (1992: 740) considered Pinter as 'absurdist', "existentialist," "anti-humanistic" and "amoral". Pinter himself believed he belonged to none of the mainstreams of the time and he liked this in fact. He liked that critics were not able to define the stream he belonged to. He just wanted to write for the sake of writing and express his interior fears caused mainly by the war and his disrupted childhood. These fears are present in all of his dramas as well as in the Birthday Party.

His famous play The Birthday Party shows the attempts of Stanley to evade all the connections of his past life and begin a new life. But Stanley does not succeed in this attempt. He becomes a pathetic figure, an embodiment of the anxiety and fear felt by the individual in the modern world., (the way Pinter felt). The past, plays a very energetic role in the relationships among characters and as in other Memory Plays of Pinter, memory is used as a weapon to gain control of other opponent characters. (Pandey. A. 2013: 19)

The Birthday Party is structured superficially like the familiar, realistic well-made play, with its exposition, complication, climax and denouement. However each of these features are subverted by the implication that factual information imparted by characters is unverifiable and their motives are ambiguous. The conversation between Meg and Petey, throws doubt upon the veracity of the information. By disrupting the structure of this well-made play, Pinter ensured that the audience would share Stanley' sense of insecurity and the feeling of inhabiting an irrational world in which anything could happen. (Peacock. D. K. 1997: 63).

When the absurdities dominate the lifestyle of individuals, this will throw them into a state of despair from which there is no escape. In the Birthday Party, everything eventually becomes unreliable, even the language. Language, as a means of communication, becomes a vehicle of conventionalized, meaningless exchange. Words fail to express the essence of human condition, not being able to penetrate beyond its surface. Words seem useless from this perspective and they cannot be used to their real function in this life, which is communication. If there is no communication there is no hope, no life and no new expectations.

They serve as a barrier between us and the outside world. Although initially critics considered Pinter's dialogue, with its contradictions, repetitions, solecism, pauses, and silences, to be ultra-naturalistic, the type of speech that might be overheard on a London bus, as his work progresses they realized that its structure was in fact highly selective. Language now ceased to be a means of interpersonal communication or a carrier of factual information, but was merged with the dramatic action as a weapon in the character's armory of evasion, "a constant stratagem for covering nakedness" (Pinter; 1962;82). The speech we hear is an indication of that which we do not hear. It is a necessary avoidance which keeps the other in its true place. When true silence falls we are left with echo but we are nearer nakedness. (Ibid, 14). Analyses of Pinter's verbal language have often been focused on how Pinter presents the problem of communication. Hollis, for example, in Harold Pinter, emphasizes that Pinter uses language in order to describe the failure of language and points out the poverty of man's communication (Hollis 13, quoted in Quigley. pp. 12-13) In such a direction, the phrase "failure of communication" has often been used as an important way to explain characteristics of Pinter's plays.

Words reveal to the audience not the character's motives or history, but only their current aims and fears. Pinter's characters do not wish to communicate: to do so would be to compromise their individuality, for as Pinter himself explained, in his plays "communication is a fearful matter" (Pinter. 1961; 257) Information imparted to another character may be turned as a weapon against its originator. The term "Failure of communication" present in The birthday party as well, is present in almost all of the absurd plays of Pinter. He believes that we communicate only too well, in our silence, in what is left unsaid, and what takes place is a continual evasion, desperate attempts, to keep ourselves to ourselves. Communication is too alarming. To enter into someone else's life is too frightening. To disclose the poverty within us is too fearsome possibility. (Pinter; 1962; 15)

Like music, absurd dramas, communicate an experience of human situations. In the absurd play The Birthday Party, the characters try to conceal their self by using language in a special way in which the mutual understanding among them is not possible; each person finds himself far from the other, completely disconnected. Either they do not communicate, or they communicate through silence, pause, repetition and non-verbal expression. The characters' words do not make any sense at all when they speak. In this play, the atmosphere is charged with fear and threat to the natural harmony of life.

Though Pinter depends on the form of comedy rather than that of tragedy, this does not decrease the hidden 
menace against the characters who want to escape from the forces of evil. Pinter likes to show the inevitable contradictions faced by people in today's world. His plays have been rightly called Comedies of Menace. The same with those written by Oscar Wilde. The heroes of Pinter are pessimistic and function as tools in the hands of unbanning powers. Like the existentialist playwrights Pinter has given expression to the hopelessness and anxiety felt by the individual in the modern society. The Birthday Party is a good sample of all of these things let's clarify it below

\section{The Birthday Party and Absurdity}

The Birthday Party has a credible dramatic situation, but not a credible plot structure, characters or any logical, linear action. In Pinter's theatre, the continuous presence of a closed room, with a few persons huddled together inside, in a sort of "non-communicative conversation", is significant. He got this example by Becket. The dramatic image of his play is based on a basic human situation: individual's search for security in a world which is full of anxiety, terror, false friendship and a lack of understanding between people. "We live on the verge of disaster" [Esslin: 1977: 23]. Esslin defined absurd as "what is devoid of purpose... Cut off from his religious, metaphysical, and transcendental roots, man is lost; all his actions become senseless, absurd, useless". ( Pinter.H., in Joseph F. McCrindle, 1971:218.)

This sense of anguish at the absurdity of human existence is broadly speaking the theme of plays of Becket, Ionesco, Genet and Pinter as well. (Ibid, 218). Some critics claim that Pinter is absolutely absurd as they see the first side; while, on the contrary, some other critics repudiate Pinter as being an absurdist writer because they see the other side. For instance, Philip Hope-Wallace (1986) regards Pinter's works as absolutely absurd, saying that "These Pinter pieces, variously amusing according to taste, and often fraught with that fashionable commodity menace, are not really "about' anything" (197)

The absurd character of Pinter is built up by three distinct elements: mystery, menace and humor. Pinter successfully creates a drama of human relations at the level of language. According to Ganz (1970:3), "The most distinctive elements in Pinter's dramatic technique are the ambiguity that surrounds events, the mysterious behaves of characters, the presence of menace, and the silences and other verbal characteristics." His characters are in fact quite mysterious and never reveal anything about their past. They are what they are, and we get to understand them and not prejudice their way of being only at the end of each play.

The plot of the play hinges on Stanley who isolates himself from the world by putting up in a squalid seaside boarding house, owned by Meg and Petey. The couple protects Stanley and tries to make him comfortable. But the peaceful atmosphere is disturbed by unexpected guests, McCann and Goldberg, the agents of unknown forces who have come to claim Stanley. The language they use is really important in understanding the sense of insecurity and to reflect the tension that is being created. In fact it is a barrier in communication. This leads characters into pauses and silences, and any verbal assertiveness causes communicative disjunction. The dialogue between Petey and Meg is more an attempt at evasion than communication. For instance, Pinter uses repetition as a way to create laughter and also to ease the tension of the scene and entertain the audience. In the first Act, Meg repeatedly asks a question to create laughter

$$
\begin{aligned}
& \text { Meg - Is that you, Petey? } \\
& \text { Pause } \\
& \text { Petey- is that you? } \\
& \text { Pause } \\
& \text { Petey? } \\
& \text { Petey - what? } \\
& \text { Meg -Is that you? } \\
& \text { Petey - Yes it's me. } \\
& \text { [The Birthday Party:24] }
\end{aligned}
$$

Absurd ideas and fanciful imagination indicate the feeling of hollowness in Meg and Petey's married life and also in Stanley's life gripped by uncertainties and insecurities. This peaceful atmosphere is disturbed by the unexpected entry of McCann and Goldberg who come to perform a "job". They not only disturb Stanley but arouse his fear for unknown reasons. And this tension passes on to Meg as Stanley starts behaving peculiarly. Pinter is more preoccupied with our fears, our anxieties that are reflected throughout the play. Meg's fear of losing Stanley, "You wouldn't have to go away if you get a job" (The Birthday Party: 9), reveals her sense of insecurity. The arrival of the two men at the boarding house reflects Stanley's fear of losing the security, which he was getting from Meg. Again, Stanley's fear becomes an inevitable cause for absurd imagination. He says:

$$
\text { "They're coming today." }
$$




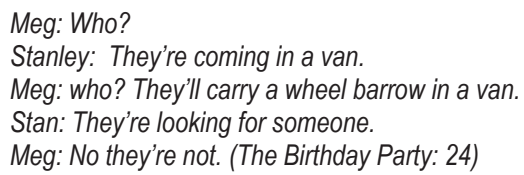

Pinter's dialogues are so well constructed that the ambiguity is maintained and several ways for interpretations are possible. In this context, Hobe (1977:418) says: "Pinter has consistently relied upon language device for his effects rather than ritualistic visual devices characteristic of the theatre of Absurd." He uses silence and pauses as mediums of communication. The characters convey a lot by being silent or giving a pause during their conversation, both the actors and the spectators are left wondering as to what would follow. Terror is intensified further with the arrival of two agents who start interrogation and cross-examination. They accuse him of unknown guilt and sins. Stanley remains speechless and only makes the inarticulate gurgling sounds. His silence only stresses the disintegration of the human personality. In this process words serve as weapons. Stanley is virtually brain-washed through a series of incomprehensible questions.

In Pinter, the structure of the dialogue plays a vital role in creating a tense dramatic atmosphere of menace, and the absurd changes, from one to another, which is a major linguistic element in The Birthday Party. Pinter arranges his words carefully, and he listens to them through silence. Dialogue is shaped on bad syntax, tedious repetitions and excruciating contradictions. Through dialogue he presents the inadequacy of the words we use. He hints at the unspoken and he creates an absurd atmosphere by means of the theatrically useful nature of words pertaining to correct rhythm.

The Birthday Party evokes a mood of terror and mystery by creating a distorted world. .lllusions, past recollections and childhood memories also become a medium for the characters to relieve their tensions and serve as an escape from the present world of brutality. Meg easily enters into her world of happy memories and illusion the next day after the Birthday Party. She is not aware of the harsh reality that Stanley had to undergo harassment, and that he was carried away by force by McCann and Goldberg. With an unconscious irony, she recollects the happy moments and insists....

"I was the belle of the ball."

Petey: Were you?

Meg: oh Yes, They all said I was Petey, I bet you were, too.

Meg - oh!. It's true, I was. (Pause) I know I was. (The Birthday Party: 59).

Another example in the drama is:

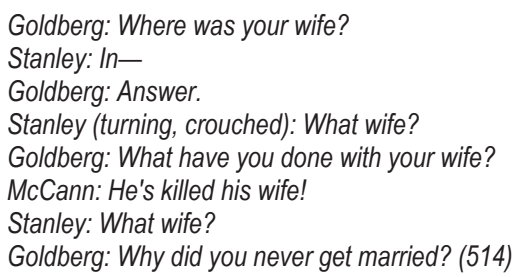

Language fails to unite these individuals and an intentional deviation from communication leads them to the solitude. Thus, the bigger questions concerning man and his position in the universe emerge: what is man and where does he really belong? Does his existence mean anything? Is he able to know the nature of his being in a world where the relationship between being and nothingness, between different entities in an undefined system of life, is contingent and arbitrary? The attempt to answer these questions associates the idea of the Absurd with the more philosophical explorations of Existentialism which opens up a new chapter in the history of man's struggle to define his being and to determine his position in the universe. The problem of verification in Pinter's theatre is closely linked with his use of language.

There are a lot of misunderstandings arising from inability to listen, incomprehension of polysyllabic words used by the more articulate characters, mishearing and false anticipations. But life in Pinter's view, like all other absurdistexistentialist writers, is a big game in which everything may happen, and the gun that you have aimed at the other, may suddenly turn back at yourself. As Buck (1997) states, ". . . the language of the text demands that we participate in a probe for meaning, but a probe that leads us down paths that are all possible at once, but questionable. In other words, we see possibilities but are sure of absolutely nothing" (45-46). 


\section{Conclusion}

As a conclusion to what we mentioned so far, we can say that Harold Pinter's plays reveal our state of isolation, alienation, nothingness and meaninglessness. In Pinter's world, language has lost its power and significance. Words do not unite but they separate, they have lost their primary function which is Communication. The characters in The Birthday Party are not capable of using the language; language for them is like movement, the irrationality, aggressiveness and violence. Absurdity engulfs everything and everyone, even language and life itself. Language, like an absurd hero, brings to the audience the absurdity of human condition. The characters feel they are outsiders and are alienated. Pinter succeeds in creating this type of drama: Man versus existence, or Man versus language. But even though we are destined to fail, at least we fail heroically in our battle between nature and us.

\section{References}

Anshu. P. (2013) Harold Pinter's Old Times, Criterion, International Journal in English, pp.19.

Buck, R. A. (1997). Pinter's The Dumb Waiter, Explicator, pp. 56 (1), 45- 48.

Peacock D. K. Harold Pinter and the New British Theatre. 1997. Greenwood Press. Westport, CT. pp.63

Esslin, . (1961) :The Theatre of the Absurd. Middlesex Penguin. pp. 202 : The Theatre of the Absurd. Middlesex Penguin. pp. 241

Esslin. M. (1974) The Peopled Wound: The plays of Harold Pinter. London: Methuen and Company.

Etheridge, J. M. (1964). Ed. Contemporary Authors: A Bibliographical Guide to Current Authors and their Works, Michigan: Gale Research Company.

Ganz. A. (1972) Pinter: A Collection of Critical Essays. Prentice Hall.

Hope-W. P. (1986). Feeling Cheated, In Michael Scott (Ed.). Harold Pinter: The Birthday Party, The Caretaker \& The Homecoming, London: MacMillan.

Hynes, J. (1992). Pinter and Morality, The Virginia Quarterly Review, 68 (4) 740751.

Pinter. H. (1960) The Birthday Party. Methuen \& Co., London.

Pinter. H. "Writing for the Theatre," 1962. pp. 82. : (1962) "Writing for the Theatre," . pp.14

: (1962)"Writing for the Theatre,", pp. 15

Pinter. H: (1960) From an interview in Monitor, BBC TV, quoted in Kay Dick, "Mr Pinter and the Fearful Matter, Texas Quarterly (Autumn 1961), pp. 257.

Pinter. H. (1971). In Joseph F. McCrindle, ed., Behind the Scenes . London: Pitman, pp. 218.

Pinter, H. (1962). The Birthday Party: Seven Plays of the Modern Theatre.

Quigley, A. E. The Pinter Problem. Princeton, N.J.: Princeton UP, 1975, pp. 12-13

Vinson, J. (1973). Ed. Contemporary Dramatists, London: St. James Press. pp. 197

Wellwarth, G. (1964). The Theatre of Protest and Paradox: Developments in the Avant-Garde Drama, London: Mac Gibbon and Kee.

Wray. H. (1977): 'Pinter's Dialogue: The play or words; Modern Drama. USA. Feb, X III. 2062 York: Grove Press. 